\title{
Diagnostic Stewardship on the Extra-Analytical Phase to Secure Quality Assurance of Diagnostic Tests for Clostridioides difficile Infection
}

\author{
Young Ah Kim, Sang Sun Lee, and Young Jun Son \\ Department of Laboratory Medicine, National Health Insurance Service Ilsan Hospital, Goyang, Korea
}

\section{Corresponding author:}

Young Ah Kim

Department of Laboratory Medicine, National Health Insurance Service Ilsan Hospital, 100 Ilsan-ro, Ilsandong-gu, Goyang 10444, Korea

Tel +82-31-900-0908

Fax +82-31-900-0925

E-mail yakim@nhimc.or.kr

Received: March 30, 2020

Revised: May 13, 2020

Accepted: May 19, 2020
This is an Open Access article distributed under the terms of the Creative Commons Attribution Non-Commercial License (http://creativecommons.org/licenses/ by-nc/4.0) which permits unrestricted non-commercial use, distribution, and reproduction in any medium, provided the original work is properly cited.
Background: Clostridioides difficile infection (CDI) is the most essential cause of antimicrobial-related diarrhea in hospitalized patients. It is also considered as an important hospital-acquired infection. Adequately performing the laboratory diagnostic tests for CDI is critical for the control and treatment of CDI in healthcare facilities. This study focused on the management of the extra-analytical phase to secure quality assurance of the diagnostic tests for CDI.

Methods: We analyzed the volume and pattern of requested $C$. difficilerelated tests from patients in 2018. The culture-positive rate was compared with the stool quality. Finally, the clinical characteristics of antibiotic-related diarrhea were compared based on whether toxigenic $C$. difficile was isolated. Results: Culture plus toxin enzyme immunoassay was the most common pattern; however, it showed low positive rates for toxigenic $C$. difficile. The culture-positive rates were not different according to the Bristol stool form scale. The significant risk factors for the detection of toxigenic $C$. difficile in patients with antibiotic-associated diarrhea were inhibitor-combined penicillin or cephalosporin (odds ratio [OR], 5.060; 95\% confidence interval [Cl], 1.317-19.447; $P=0.0183$ ) and extended-spectrum cephalosporin (OR, $16.224 ; 95 \% \mathrm{Cl}, 3.166-83.134 ; P=0.0008)$.

Conclusions: The pre-pre-analytical errors are easy to overlook in routine laboratory procedures. Our findings could provide a good example of the management of the extra-analytical phase to secure quality assurance of the diagnostic tests for CDI.

\section{(Lab Med Qual Assur 2020;42:77-83)}

Key Words Clostridioides difficile, Diagnostic stewardship, Pre-pre-analytical error
서론

임상검사의 질보증을 위해서는 부정확한 검사결과를 야기하 는 검사오류를 개선할 필요가 있다. 검사오류는 흔히 검사 전 오 류(pre-analytical), 검사오류(analytical error) 및 검사 후 오류 (post-analytical)로 구분하며, 잘 알려진 검사 전 오류의 원인으 로는 환자-검체 혼동, 부적절한 검체 채취, 부적절한 검사용기 사
용, 부적절한 검체 수송 등이 있다[1]. 검사오류의 원인으로는 장 비오류, 검체 혼동, 간섭물질 및 정도관리 오류 등이 있으며, 검사 후 오류의 주요 원인으로는 검사보고의 과도한 지연, 수기오류, 부 적절한 검사결과의 해석 등을 들 수 있다[1]. 하지만 최근에는 검 사의 처방과 관련된 pre-pre-analytical error와 검사결과가 보 고된 이후 이에 따른 환자 처치에 관련된 post-post-analytical error를 관리의 중요성에 대해서도 강조되고 있다[2,3]. 
Clostridioides (Clostridium) difficile은 항균제 관련 설사 (antibiotic-associated diarrhea) 및 항균제 사용 후 발생한 위 막성 대장염(pseudomembranous colitis)의 주된 원인균으로 알려져 있다[4]. C. difficile 감염(C. difficile infection)의 진단을 위해서는 설사나 24시간 이내 3회 이상의 묽은 변에서 독소를 생 성하는 C. difficile를 확인할 필요가 있다. 검사실에서 통상적으로 사용하는 C. difficile 검사법으로는 변 검체를 이용한 C. difficile 배양, 중합효소연쇄반응(polymerase chain reaction, PCR) 로 독소 $A / B$ 유전자를 검출하는 방법, 효소면역분석법(enzyme immunoassay, EIA)로 독소 $A / B$ 나 glutamate dehydrogenase $(\mathrm{GDH})$ 를 검출하는 방법 등이 있다[5,6].

본 연구의 목적은 C. difficile 관련 검사를 통해 pre-preanalytical error의 관리에 중점을 둔 diagnostic stewardship 의 적용의 예를 알아보는 것이다. 이를 위하여 먼저 C. difficile 관 련 검사들의 연간 검사량과 검사패턴을 분석하여 검사 의뢰가 적 절한지 알아보았다. 변 성상에 따른 배양 양성률도 알아보았는데, 이의 목적은 비정형변을 보는 환자에서 C. difficile 배양 의뢰를 적극적으로 추천할 필요가 있는지 파악하고자 함이다. 마지막으로 항균제 관련 설사가 의심되는 환자에서 C. difficile 관련 검사가 필요한 위험인자를 파악하기 위해서 독소 생성 C. difficile이 분리 된 경우와 C. difficile 배양 음성 환자의 임상적 특성을 비교하였 다.

\section{재료 및 방법}

\section{1. 대상}

국민건강보험공단 일산병원에서 2018년 1월부터 12월까지 내 원한 환자 중 항균제 관련 설사 환자로 C. difficile 관련 검사를 의 뢰한 환자를 대상으로 하였다.

\section{C. difficile 진단검사법}

C. difficile 배양검사는 변 검체를 ChromID C. difficile agar (bioMérieux, Marcy-l'Etoile, France)에 도말하여 혐기성 조건 에서 24시간 배양하였으며, 특징적인 검은색 집락, 냄새, 그람염 색 성상 및 RapID32A strips (bioMérieux)를 이용하여 동정하였 다. 독소검사용 VIDAS C. difficile Toxin A\&B (bioMérieux)와 독 소 유전자 검사용 Xpert C. difficile assay (Cephid, Sunnyvale, CA, USA)를 제조사의 지침에 따라 시험하였다.

\section{3. 검사 현황}

본원에서 시행 중인 L41046 C. difficile culture(배양), L5501

C. difficile toxin A\&B assay(독소 EIA), 및 L9019 C. difficile toxin Xpert (PCR) 의뢰 현황을 전산으로 추출하여 월별, 진료 과별 검사량을 분석하였다. 같은 자료로 처방패턴도 분석하였는 데, 3 일 이내 C. difficile 배양, 독소 EIA, 및 PCR이 의뢰된 경우 는 동시에 의뢰된 것으로 하였다. 중복을 최소화하기 위하여 60 일 이내에 다시 진단받은 경우 연구대상에서 제외하였는데, 이는 $C$. difficile 재발의 정의가 치료 종료 후 8주 이내에 다시 치료를 받 는 것임을 고려하였다[6]. 독소를 생성하는 균주만이 감염을 일으 키므로, 각 처방패턴에 따른 독소 생성 C. difficile의 검출률을 살 펴보았다. 단독검사가 아닌 경우 독소 생성 C. difficile의 검출은 배양과 독소검사가 함께 의뢰된 경우(배양+PCR, 배양+독소 EIA, 배양+독소 EIA+PCR)는 배양에서 C. difficile이 분리되고 독소 EIALㄴ PCR 양성인 경우로 하였다. 배양을 시행하지 않은 경우 독 소 EIA와 PCR 중 하나라도 양성이면 독소 생성 C. difficile이 검 출된 것으로 하였다. 배양만 의뢰된 경우 독소 생성 유무를 판단할 수 없으므로 분석에서 제외하였다.

\section{4. 변 성상에 따른 C. difficile 배양 양성률}

접수된 변 검체를 Bristol Stool Form Scale에 따라 접수된 변 성상을 구분하여, 이에 따른 C. difficile 배양 양성률을 비교하였 다[7]. 본원에서는 고형 변(1-4형)은 접수를 거절하고 있으므로 분석에 포함되지 않았고, 변 검체의 유형은 5형(soft blobs with clear-cut edges), 6형(fluffy pieces with ragged edges) 및 7 형(watery, no solid pieces, entirely liquid)으로 구분하였다.

\section{5. 항균제 관련 설사 환자의 임상적 특성}

항균제 관련 설사 환자가 의심되는 환자는 C. difficile 관련 검 사가 의뢰된 환자로 정의하였고, 이중 독소 생성 C. difficile가 분 리된 60 명(환자군)과 C. difficile 배양 음성 60명(대조군)을 무작 위로 추출하여 후향적 환자-대조군 연구를 통해 위험인자를 파악 하였다. 환자군은 배양에서 C. difficile가 분리되고 독소 EIA나 $\mathrm{PCR}$ 양성인 경우와 배양 의뢰가 없더라도 PCR 양성인 경우로 정 의하였다. 전자의무기록을 통해 나이, 성별, 의뢰과, 요양원 전원, 중환자실 입실 유무, 1 개월 이내의 항균제 사용, 항암치료, proton pump inhibitor 사용력 및 이전 3 개월 내 C. difficile의 분리 유 무 등의 관련 자료를 수집하였다.

\section{6. 통계분석}

범주형 범수의 단변량분석에는 Fisher's exact test와 chisquare test를 사용하고, 비정규 분포 변수에서는 MannWhitney U-test를 사용하였다. 단변량분석에서 $P$-value $<0.1$ 인 경우 multivariable logistic regression으로 다변량분석을 시행 하였다. IBM SPSS software ver. 23.0 (IBM Corp., Armonk, 
NY, USA)을 통계분석에 사용하였다.

\section{결과}

\section{1. 검사의뢰 현황 및 처방패턴}

2018년 의뢰된 총 4,451건의 C. difficile 배양, 독소 EIA, 및 $\mathrm{PCR}$ 검사를 분석하였을 때 연간 검사 의뢰양은 계절에 따른 차
이를 보이지 않았고(Fig. 1A), 의뢰가 많은 과는 호흡기내과, 소화 기내과, 감염내과, 응급의학과, 신장내과 및 혈액종양내과 순이 었다(Fig. 1B). C. difficile 관련 검사별 양성률은 배양이 $23.2 \%$ (420/1,808), 독소 EIA가 $10.4 \%$ (209/2017), PCR법이 25.7\% (161/626)였다.

60 일 이내 재의뢰된 경우는 첫 번째 처방패턴만 포함하여 총 1,644 건을 분석하였다. 배양과 독소 EIA를 같이 실시하는 경우가
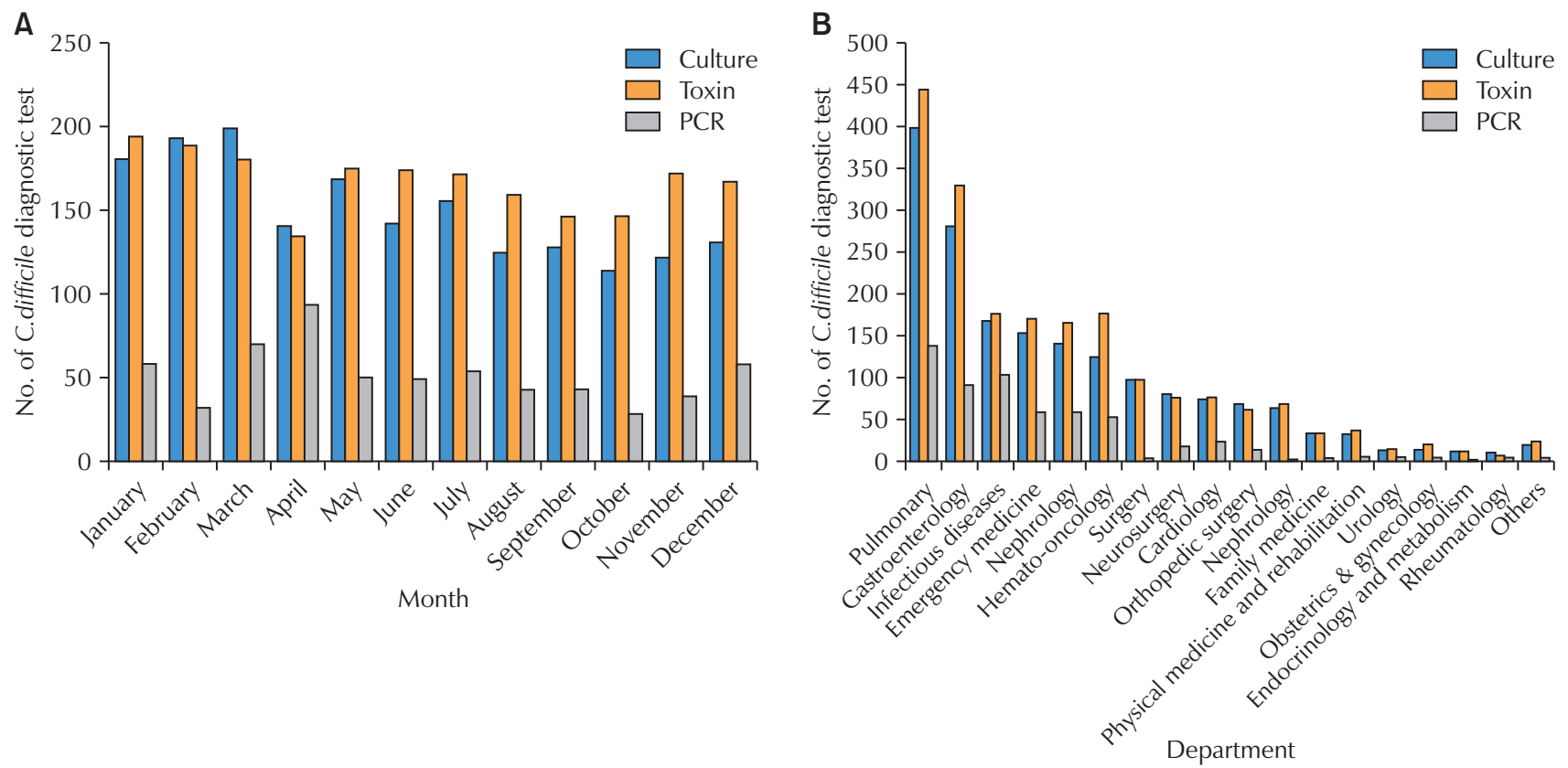

Fig. 1. The number of $C$. difficile diagnostic test according to season (A) and referral departments (B). Abbreviations: $C$. difficile, Clostridioides difficile; Culture, C. difficile culture; Toxin, C. difficile toxin A\&B assay; PCR, Xpert C. difficile assay.

A

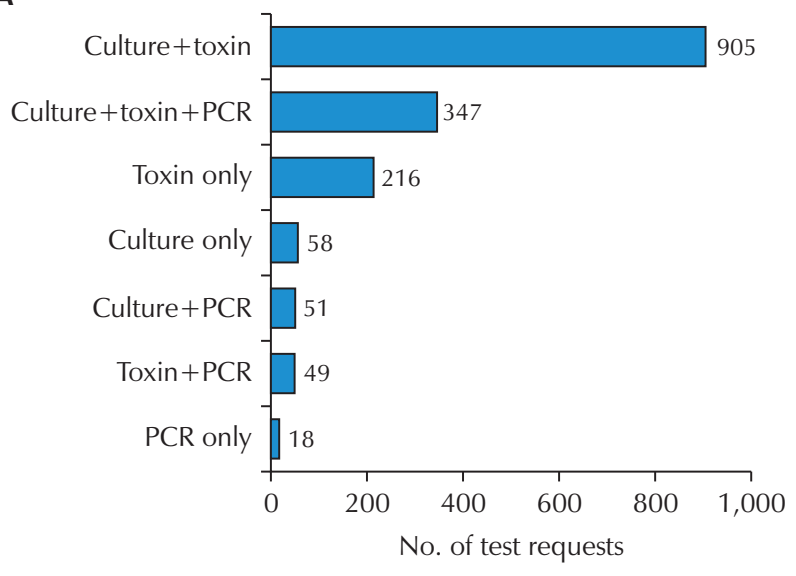

B

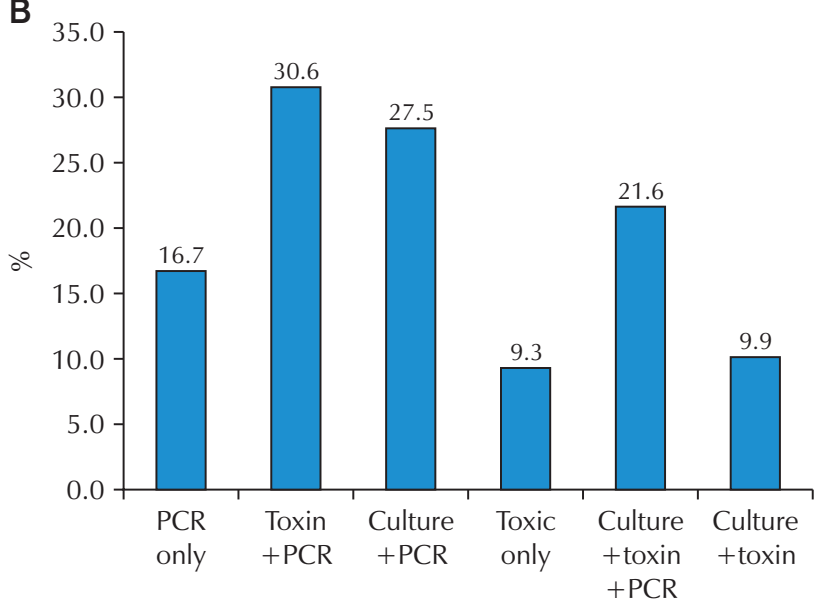

Fig. 2. The request patterns for $C$. difficile diagnosis and detection rates of toxigenic $C$. difficile. (A) Number of test requests by test combination. (B) Positive rate according to the type of test requested. Abbreviations: $\mathrm{C}$. difficile, Clostridioides difficile; Culture, $\mathrm{C}$. difficile culture; Toxin, $C$. difficile toxin A\&B assay; PCR, Xpert $C$. difficile assay. 
Table 1. C. difficile culture positive rates according to Bristol stool scale [6]

\begin{tabular}{cccc}
\hline Type & $\begin{array}{c}\text { No. of } C \text {. difficile } \\
\text { culture (\%) }\end{array}$ & $\begin{array}{c}\text { Culture } \\
\text { positive } \\
\text { rates (\%) }\end{array}$ & $P$-value \\
\hline 5 & $310(37.2)$ & 23.2 & 0.2045 \\
\hline 6 & $259(31.0)$ & 23.9 & \\
\hline 7 & $265(32.8)$ & 18.1 & \\
\hline
\end{tabular}

Abbreviation: C. difficile, Clostridioides difficile.
가장 많았고, 배양, 독소 $\mathrm{EIA}$, 및 $\mathrm{PCR}$ 을 모두 의뢰하는 경우가 그 다음이었고, 독소 EIA만 의뢰하는 경우도 적지 않았다(Fig. 2A). 독소를 생성하는 C. difficile만이 감염의 원인이 되므로, 처방패턴 에 따라 독소 생성 C. difficile의 검출률을 살펴보았다. 독소 EIA와 $\mathrm{PCR}$ 의 경우 $30.6 \%$, 배양과 $\mathrm{PCR}$ 이 $27.5 \%$, 세 가지 모두 의뢰한 경우 $21.6 \%, \mathrm{PCR}$ 만 의뢰한 경우 $16.7 \%$, 배양과 독소 $\mathrm{EIA}$ 혹은 독소 EIA만 단독으로 의뢰한 경우 $10 \%$ 미만이었다(Fig. 2B).

\section{2. 변 성상에 따른 C. difficile 배양 양성률}

C. difficile 배양이 의뢰된 총 834검체에서 변 성상을 Bristol

Table 2. Univariate analysis of risk factors for the isolation of toxigenic C. difficile in patients with antibiotic-associated diarrhea

\begin{tabular}{|c|c|c|c|}
\hline Variable & $\begin{array}{l}\text { With toxigenic } \\
\text { C. difficile }(\mathrm{N}=60)\end{array}$ & $\begin{array}{c}\text { Without } \\
\text { C. difficile }(\mathrm{N}=60)\end{array}$ & $P$-value \\
\hline Age (yr) & $74.7 \pm 14.1$ & $69.0 \pm 18.1$ & 0.0731 \\
\hline Male sex & $25(41.7)$ & $34(56.7)$ & 0.1073 \\
\hline \multicolumn{4}{|l|}{ Referral department } \\
\hline Emergency room & $12(20.0)$ & $2(3.3)$ & 0.0120 \\
\hline Medical & $36(60.0)$ & $50(83.3)$ & 0.0057 \\
\hline Surgical & $10(16.7)$ & $8(13.3)$ & 0.6093 \\
\hline Other* & $2(3.3)$ & 0 & 0.9868 \\
\hline Long-term care facility transfer & $8(13.3)$ & $4(6.7)$ & 0.2650 \\
\hline Intensive care unit admission & $5(8.3)$ & $5(8.3)$ & 1.0000 \\
\hline \multicolumn{4}{|l|}{ Previous antibiotics (<1 mo) } \\
\hline Any antibiotics & $55(91.7)$ & $44(73.3)$ & 0.0151 \\
\hline Penicillin & $16(26.7)$ & 0 & 0.0108 \\
\hline Inhibitor combination & $9(15.0)$ & $25(41.7)$ & 0.0022 \\
\hline Aminoglycoside & $1(1.7)$ & 0 & 0.6265 \\
\hline Fluoroquinolone & $8(13.3)$ & $18(30.0)$ & 0.0355 \\
\hline Narrow spectrum-cephalosporin & $5(8.3)$ & $8(13.3)$ & 0.4131 \\
\hline Extended spectrum-cephalosporin & $4(6.7)$ & $16(26.7)$ & 0.0081 \\
\hline Teicoplanin & 0 & $3(5.0)$ & 0.2553 \\
\hline Fosfomycin & $1(1.7)$ & 0 & 0.6265 \\
\hline Carbapenem & $8(13.3)$ & $1(1.7)$ & 0.0509 \\
\hline Cotrimoxazole & $1(1.7)$ & $2(3.3)$ & 0.6623 \\
\hline Azithromycin & $1(1.7)$ & $4(6.7)$ & 0.2730 \\
\hline Previous chemotherapy (<1 mo) & $3(5.0)$ & $5(8.3)$ & 0.5156 \\
\hline Proton pump inhibitor (<1 mo) & $11(18.3)$ & $10(16.7)$ & 0.8178 \\
\hline C. difficile isolation history (<3 mo) & $5(8.33)$ & $1(1.67)$ & 0.1307 \\
\hline
\end{tabular}

Values are presented as mean \pm standard deviation or number (\%). Toxigenic $C$. difficile: defined as the case in which $C$. difficile were isolated from culture and toxin production was confirmed by enzyme immunoassay or polymerase chain reaction was positive. Abbreviation: $\mathrm{C}$. difficile, Clostridioides difficile.

${ }^{\star}$ Rehabilitation department. 
Stool Form Scale로 판정하였고, 이 중 5형이 37\% (310/834), 6 형이 $31 \%$ (259/834)로 묽은 변이 전체의 $68 \%$ 였고 7형인 설사 변이 32\% (265/834)이었다(Table 1). 변 성상에 따라 배양 양성 률은 score 5-7 사이에는 차이가 없었다 $(P=0.2045)$. 임상의에게 변 성상에 대해 정보를 제공한 2018년 6월 이후와 그 이전의 C. difficile 배양 양성률은 각각 $24.4 \%$ 와 $21.8 \%$ 로 차이가 없었다 $(P=0.1897)$.

\section{3. 항균제 관련 설사 환자의 임상적 특성}

단변량분석에서 $P<0.1$ 인 변수들로 다변량분석을 시행하여 (Table 2), 페닐실린(혹은 세팔로스포린)과 억제제 복합제(odds ratio [OR], 5.060; 95\% confidence interval [Cl], 1.31719.447; $P=0.0183$ )와 광범위 세팔로스포린(OR, $16.224 ; 95 \%$ $\mathrm{Cl}, 3.166-83.134 ; P=0.0008)$ 이 항균제 관련 설사 환자에서 독소 생성 C. difficile 분리의 주요 위험인자임을 확인하였다(Table 3).

\section{고찰}

국내에서는 환자안전법의 강화로 의료영역에서 환자안전이 강 조되고 있고, 의료비 지불제도에서 진단명에 따라 일정한 금액을 책정하는 '신포괄수가제'가 전반적으로 확대될 가능성이 있다. 이 러한 경우 진단검사의학과 의사의 역할이 신규검사 셋업 및 검사

Table 3. Multivariate analysis of risk factors for the isolation of toxigenic $C$. difficile in patients with antibiotic-associated diarrhea

\begin{tabular}{lcc}
\hline \multicolumn{1}{c}{ Variable } & $\begin{array}{c}\text { Odds ratio (95\% } \\
\text { confidence interval) }\end{array}$ & $P$-value \\
\hline Age & $0.960(0.928-0.993)$ & 0.0173 \\
\hline Referral department & & \\
\hline Emergency room & $0.142(0.016-1.274)$ & 0.8120 \\
\hline Medical & $2.223(0.631-7.827)$ & 0.2136 \\
\hline Previous antibiotics & & \\
\hline Any antibiotics & $0.102(0.024-0.431)$ & 0.0019 \\
\hline Penicillin & $0.053(0.002-1.347)$ & 0.0752 \\
\hline Inhibitor combination & $5.060(1.317-19.447)$ & 0.0183 \\
\hline Fluoroquinolone & $3.995(0.856-18.649)$ & 0.0781 \\
\hline $\begin{array}{l}\text { Extended spectrum- } \\
\text { cephalosporin }\end{array}$ & $16.224(3.166-83.134)$ & 0.0008 \\
\hline Carbapenem & $0.033(0.003-0.359)$ & 0.0051 \\
\hline
\end{tabular}

Toxigenic $C$. difficile: defined as the case in which $C$. difficile were isolated from culture and toxin production was confirmed by enzyme immunoassay or polymerase chain reaction was positive. Abbreviation: $C$. difficile, Clostridioides difficile.
의 질 보증 등의 기존의 업무 외에 효율적 검사의뢰 및 검사결과를 환자의 진료에 적절하게 적용하는 것을 관리하는 영역까지 확대될 필요가 있다. 정확하고 효율적인 검사를 위해서는 통상적인 검사 실 관련 오류뿐 아니라 검사실 밖에서 검사 관련 인력과 무관하게 발생하는 extra-analytical error의 관리도 중요하다[2,3]. 이 중 부적절한 검사의 선택과 관련된 pre-pre-analytical error가 드물 지 않은 것으로 보고되어 있다[3].

C. difficile 감염은 항균제 내성분야에서 주요 위협으로 간주 되고 있고[8], 병원감염뿐 아니라 지역사회 분리가 증가하고 있 다[9]. 하지만 많은 임상의사들이 다른 다제내성균에 비해 C. difficile 감염에 대한 관심이 적어 관련된 진단을 검사법 간의 차 이, 적절한 환자의 선택 및 검사결과의 해석에 충분한 정보를 갖고 있지 못한 경우가 많다. 본 연구에서 C. difficile 관련 검사의 적절 한 운영을 위해 통상적인 정도관리에서 간과하기 쉬운 검사 처방 과 관련된 pre-pre-analytical error의 본원 개선방안을 모색하고 자 하였다.

C. difficile 관련 검사법 중 배양은 민감도가 우수하지만 검사 소요시간이 48시간 이상 걸리고, 독소를 생성 여부에 상관없이 모 든 C. difficile이 배양되어 특이도가 낮은 단점이 있다[6]. 이에 비 해 변에서 직접 PCR로 독소 $\mathrm{A}$ 및 $\mathrm{B}$ 유전자를 검출하는 방법은 가 장 민감하고 특이적이나 검사비용이 비싼 단점이 있으며 죽은 세 포에 의한 위양성과 변 검체 내에 존재하는 PCR 저해인자에 의한 위음성 가능성이 있다[6]. 변 검체에서 EIA로 독소 A 및 B를 검출 하는 방법은 좀 더 저렴하고 자동화된 장비를 이용하여 쉽게 할 수 있으나, 민감도가 충분하지 않다[6]. GDH는 C. difficile 균의 세포 벽에 흔히 존재하며, EIA로 GDH를 검출하는 것도 민감도가 좋으 나 독소 생성에 상관없이 검출되므로 비특이적 시험이다[10].

본 연구를 통해 원내 처방패턴분석에서 독소 생성 유무를 확인 할 수 없는 배양만 의뢰하는 경우가 적지 않음을 확인하였고, 독소 EIA 단독이나 배양과 독소 EIA만 의뢰하여 독소 생성 C. difficile 검출이 매우 낮은 경우도 확인할 수 있었다. 이에 비해 독소 EIA와 $\mathrm{PCR}$ 검사 혹은 배양과 $\mathrm{PCR}$ 검사의 조합이 독소 생성 C. difficile 을 효과적으로 검출할 수 있었다. 이를 바탕으로 관련 검사의 의뢰 가 많은 호흡기내과, 소화기내과, 감염내과, 응급의학과, 신장내과 및 혈액종양내과를 중심으로 분자유전검사를 기본으로 독소 혹은 배양검사를 추가할 것을 권고하였다.

C. difficile 감염 진단을 위한 검사법은 장단점이 있기 때문에, C. difficile 감염 진단알고리즘을 확립할 필요성이 있다. 국내에 는 확립된 가이드라인이 없지만, 국외에서는 진단을 위한 가이 드라인에 대해 많은 연구가 있다. Infectious Diseases Society of America 및 Society for Healthcare Epidemiology of America의 최신 가이드라인에 따르면 24시간 이내 3회 이상 비 
정형 변을 보는 경우 C. difficile 검사를 시행하며, 대변 검체에 서 단독으로 nucleic acid amplification test (NAAT)를 처방하 거나 독소 $\mathrm{EIA}$ 를 GDH나 NAAT와 병합하여 다단계 알고리즘으로 처방할 것을 추천하고 있다[11]. European Society of Clinical Microbiology and Infectious Diseases의 최신 가이드라인에서 는 단독검사보다는 병합검사를 추천하며, NAAT이나 GDH EIA 검 사 후 독소 $\mathrm{EIA}$ 를 단계적으로 시행할 것을 권고하고 있다[12]. 다 른 방법으로는 독소 $\mathrm{EIA}$ 와 GDH EIA를 동시에 시행하여 두 검사의 결과가 다른 경우 NAAT나 배양을 추천하고 있다[12].

본 연구에서는 정보 제공 전후와 변 성상에 따라 C. difficile 배 양 양성률을 비교해 보았는데, 임상의에게 변 성상에 관한 정보를 제공하는 것이 배양 양성률에 영향을 주지 않았고, 고형변을 제외 한 Bristol Stool Form Scale 5-7형 간에도 배양 양성률에 차이 가 없었다. 따라서 변 성상이 설사변이 아니더라도 고형변이 아닌 비정형 변체(Bristol Stool Form Scale 5형, 6형)라면 C. difficile 배양검사를 적극적으로 추천하는 것이 좋을 것으로 판단하였다. 본 연구에서 정보 제공 전후 접수된 변 성상의 비율이 차이를 보였 는지는 분석할 수 없었는데, 그 이유는 변 성상 정보 제공 전 지침 에서는 고형 변의 접수를 거절하지만 변 성상에 대한 내용을 기록 하지 않았기 때문이다.

본 연구에서 페닐실린(혹은 세팔로스포린)-억제제 복합제(OR, 5.060)와 광범위 세팔로스포린의 사용력(OR, 16.224)이 주요 위 험인자였고, 카바베넴 사용력(OR, 0.033)은 반대로 위험을 낮춰
줌을 확인하였다. 설사 환자에서 카바페넴 등의 항균제 사용은 잘 알려진 C. difficile 감염의 주요 위험인자로 알려져 있지만[13], 본 연구에서 상이한 결과를 보이는 것은 기존의 연구는 대조군으 로 항균제를 사용하지 않은 그룹이었지만 여기에서는 항균제 관련 설사가 의심되지만 배양에서 C. difficile가 검출되지 않은 경우로 비교 대상이 차이가 있었기 때문이다. 이렇게 연구를 디자인한 이 유는 항균제 사용 후 발생한 설사 환자에서 독소 생성 C. difficile 의 검출과 관련된 위험인자를 파악하면, C. difficile 관련 검사를 독려할 적절한 검사 대상을 설정하는 데 도움이 되기 때문이다. C. difficile 감염의 위험인자로 알려진 proton pump inhibitors와 항암제의 사용력은 항균제 관련 설사 환자에서 C. difficile가 검출 유무에 영향을 주지 않았다[13,14].

본 연구를 통해 C. difficile 관련 검사의 처방패턴을 개선할 필 요가 있음을 확인하였다. 검사실의 질 보증을 위해서는 주기적으 로 관련 검사패턴을 분석하여 임상의들에게 필요한 정보를 제공하 는 것이 도움이 될 것으로 생각된다.

\section{감사의 글}

이 연구는 대한임상정도관리협회의 학술연구과제 연구비 지원 으로 수행되었다(과제번호: 2018-04). 통계분석을 도와주신 연구 분석팀의 윤소라 박사님께 감사드린다.

\section{REFERENCES}

1. Mohammedsaleh ZM, Mohammedsaleh F. A review article of the reduce errors in medical laboratories. Glob J Health Sci 2014;7:46-51.

2. Carraro P, Zago T, Plebani M. Exploring the initial steps of the testing process: frequency and nature of prepreanalytic errors. Clin Chem 2012;58:638-42.

3. Laposata M, Dighe A. "Pre-pre" and "post-post" analytical error: high-incidence patient safety hazards involving the clinical laboratory. Clin Chem Lab Med 2007;45:712-9.

4. Del Prete R, Ronga L, Addati G, Magrone R, Abbasciano A, Decimo M, et al. Clostridium difficile: a review on an emerging infection. Clin Ter 2019;170:e41-7.

5. Dubberke ER, Carling P, Carrico R, Donskey CJ, Loo VG, MCDonald LC, et al. Strategies to prevent Clostridium difficile infections in acute care hospitals: 2014 update. Infect Control Hosp Epidemiol 2014;35:628-45.

6. Guery B, Galperine T, Barbut F. Clostridioides difficile: diagnosis and treatments. BMJ 2019;366:14609.

7. Blake MR, Raker JM, Whelan K. Validity and reliability of the Bristol Stool Form Scale in healthy adults and patients with diarrhoea-predominant irritable bowel syndrome. Aliment Pharmacol Ther 2016;44:693-703.

8. Centers for Disease Control and Prevention. Antibiotic resistance threats in the United States, 2013. https://www.cdc. gov/drugresistance/threat-report-2013/index.html (Accessed 2020 May 20).

9. Kim YA, Rim JH, Choi MH, Kim H, Lee K. Increase of Clostridium difficile in community; another worrisome burden 
for public health. Ann Clin Microbiol 2016;19:7-12.

10. Carman RJ, Wickham KN, Chen L, Lawrence AM, Boone JH, Wilkins TD, et al. Glutamate dehydrogenase is highly conserved among Clostridium difficile ribotypes. J Clin Microbiol 2012;50:1425-6.

11. McDonald LC, Gerding DN, Johnson S, Bakken JS, Carroll KC, Coffin SE, et al. Clinical practice guidelines for Clostridium difficile infection in adults and children: 2017 update by the Infectious Diseases Society of America (IDSA) and Society for Healthcare Epidemiology of America (SHEA). Clin Infect Dis 2018;66:987-94.

12. Crobach MJ, Planche T, Eckert C, Barbut F, Terveer EM, Dekkers OM, et al. European Society of Clinical Microbiology and Infectious Diseases: update of the diagnostic guidance document for Clostridium difficile infection. Clin Microbiol Infect 2016;22 Suppl 4:S63-81.

13. King RN, Lager SL. Incidence of Clostridium difficile infections in patients receiving antimicrobial and acidsuppression therapy. Pharmacotherapy 2011;31:642-8.

14. Pant C, Madonia P, Minocha A. Does PPI therapy predispose to Clostridium difficile infection? Nat Rev Gastroenterol Hepatol 2009;6:555-7. 